\title{
Analisis Perancangan Sistem Informasi Pendaftaran Siswa Baru (PSB) Kafila International Islamic School
}

\author{
Aditya Teguh Septoaji ${ }^{1}$, A'ang Subiyakto ${ }^{2}$
}

\begin{abstract}
Kafila International Islamic School adalah sebuah pesantren yang mempunyai prestasi tinggi di tiap perlombaan dan nilai Ujian Nasional. Perekrutan siswa baru masih menggunakan metode lama, yaitu pemberkasan manual yang kemudian discan dan disimpan digital. Menggunakan cara tersebut untuk proses seleksi akan membutuhkan banyak sekali sumber daya baik manusia maupun alat. Dengan proes pendaftaran siswa baru saat ini yang masih manual membuat pekerjaan tidak efisien dan cenderung melakukan kesalahan karena ketidaktelitian pada pemberkasan. Ketidaktelitian tersebut menyebabkan beberapa kesalahan fatal, yaitu proses penerimaan siswa baru yang tidak efisien hingga hilangnya berkas siswa. Untuk menanggulangi itu, perlu sebuah sistem yang menangani pendaftran siswa baru, mulai dari data siswa, biografi siswa, hingga dokumen-dokumen siswa di sekolah. Maka dari itu, penulis membuat analisis dan perancangan Aplikasi Sistem Informasi Pendaftaran Siswa Baru (PSB) Berbasis Web dengan menggunakan Pemodelan Unified Modelling Language (UML) sebagai Bahasa pemodelannya. Dengan adanya Racangan Sistem Informasi Pendaftaran ini, semoga dapat memberikan efisiensi waktu dan proses pendaftaran yang lebih rapih dan terdokumentasi.
\end{abstract}

Keywords - Sistem Informasi, Pendaftaran, KIIS, Unified Modelling Language.

$\mathrm{D}$

\section{Pendahuluan} signifikan dalam berbagai bidang, sangat terlihat pada penggunaan teknologi informasi beberapa dekade terakhir ini dengan hadirnya berbagai aplikasi yang dapat mempermudah pekerjaan/kegiatan manusia [1]. Pada dasarnya, dengan proses yang berbeda namun tetap menghasilkan tujuan yang sama sudah sering terjadi, seperti toko fisik menjadi toko online, arsip yang diatur lewat Sistem Informasi Manajemen Kearsipan, Banking Online, dan lainnya. Namun masih ada beberapa tempat/organisasi yang belum dapat memanfaatkan teknologi informasi dengan maksimal [2]. Dan hal yang cukup memudahkan bagi penyedia produk adalah adanya sistem yang mampu beradaptasi dengan lingkungan bisnis, dalam hal ini adalah pemanfaatan teknologi yang tepat dalam penjualan produk, yang sudah menjamah pelanggan [3].

Received: 20 Juli 2019 ; Revised: 1 September 2019 ; Accepted: 5 September 2019

http://journal.uinjkt.ac.id/index.php/aism
Sebelumnya pendaftaran siswa baru Kafila International Islamic School (KIIS) menggunakan pemberkasan manual, kini sudah menggunakan teknologi informasi yang memudahkan pengumpulan berkas sejak dini. Selain dipandang sangat tidak efisien dalam mengelola berkas, akan ada kecelakaan yang serius apabila data komputer admin sekolah corrupted, atau tidak terbaca. Selalu membutuhkan backup data online seperti Google Drive, namun akan sangat riskan lagi apabila disimpan dalam arsip online yang bukan merupakan kepunyaan sekolah, karena rawan pencurian data dan penyalahgunaan data oleh pihak ketiga. Oleh karena itu penulis membantu programmer Kafila International Islamic School dalam membangun sebuah sistem pendaftaran online sehingga dapat memudahkan pengelolaan berkas siswa dan sekolah memiliki server yang menghindari kehilangan, penyalahgunaan data oleh pihak ketiga serta mampu memanajemen data dengan baik dalam pemberkasan. Dari uraian tersebut, penulis membuat laporan Praktek Kerja Lapangan (PKL) ini dengan judul "Analisis Dan Perancangan Sistem Informasi Pendafaran Siswa Baru Online Berbasis Web pada Kafila International Islamic School".

\section{KAJIAN PENELITIAN}

A. Sistem

Sistem merupakan sebuah kumpulan elemen/fungsi yang saling terkoneksi satu sama lain yang membentuk kesatuan dalam mencapai tujuan yang sama [4], misalkan dalam sebuah sekolah, yang dimaksud elemen adalah divisi internalnya seperti guru, admin, kepala laboratorium, kepala sekolah, hingga panitia penerimaan siswa baru (PSB) dan sebagainya yang semua itu terkait satu sama lain [5].

B. Informasi

Informasi merupakan data yang telah diklasifikasi untuk digunakan dalam proses pengambilan Keputusan (decision)[4]. Sistem pengolahan informasi mengolah data menjadi informasi atau tepatnya mengolah data dari bentuk tak berguna (raw) menjadi berguna untuk menunjang keputusan tersebut [6]. Nilai informasi berhubungan erat dengan keputusan, maka kualitas informasi yang tinggi akan membuat pembuat kebijakan

A. T. Septoaji1, Kafila Internasional Islamic School, Indonesia (e-mail: adityat626@gmail.com)

A. Subiyakto, Prodi Sistem Informasi, UIN Syarif Hidayatullah Jakarta, Indonesia (e-mail: aang_subiyakto@uinjkt.ac.id) 
(decision maker) mengambil langkah yang lebih tepat dan rasional [7].

\section{Sistem Informasi}

Sistem Informasi adalah suatu sistem di dalam suatu organisasi yang mempertemukan kebutuhan pengolahan transaksi harian yang mendukung fungsi operasi organisasi [8] yang bersifat manajerial dengan kegiatan strategi dari suatu organisasi untuk dapat menyediakan kepada pihak luar tertentu dengan laporan-laporan yang diperlukan.

\section{Data}

Sumber dari informasi disebut data. Data merupakan bentuk jamak dari bentuk tunggal datum. Data adalah kenyataan yang menggambarkan suatu kejadian-kejadian dan kesatuan nyata [9]. Kejadian-kejadian adalah sesuatu yang terjadi pada saat tertentu di dalam dunia bisnis. Bisnis adalah perubahan dari suatu nilai yang disebut transaksi. Misalnya, penjualan adalah transaksi perubahan nilai barang menjadi nilai uang atau nilai piutang dagang.

\section{E. Rapid Application Development (RAD)}

Rapid Aplication Development (RAD) adalah sebuah proses perkembangan perangkat lunak sekuensial linier yang menekankan siklus perkembangan dalam waktu yang singkat [10]. RAD menggunakan metode iteratif (berulang) dalam mengembangkan sistem dimana working model (model bekerja) sistem dikonstruksikan di awal tahap pengembangan dengan tujuan menetapkan kebutuhan (requirement) pengguna dan selanjutnya disingkirkan [11].

\section{F. Unified Markup Language (UML)}

UML merupakan salah satu standar bahasa yang biasa digunakan khususnya pada dunia industri yang berguna untuk mendefinisikan requirement, membuat analisis dan desain, serta menggambarkan arsitektur dalam pemrograman berorientasi objek[12]

\section{G. Website}

Website merupakan sebuah media informasi berbasis jaringan komputer yang dapat diakses dimana saja dengan biaya yang relative [13].

\section{H. $H T M L$}

HTML (Hyper Text Markup Language) adalah sekumpulan simbol-simbol atau tag-tag yang dituliskan dalam sebuah file yang dimaksudkan untuk menampilkan halaman pada web browser [14]. Tag-tag tadi memberitahu browser bagaimana menampilkan halaman web dengan lengkap kepada pengguna.

Tag-tag HTML selalu diawali dengan $\langle x\rangle$ dan diakhiri dengan $\langle/ x\rangle$ dimana $x$ tag HTML seperti $b$, i, u dan sebagainya.

\section{Metode Penelitian}

\section{A. Wawanacra}

Penulis mengadakan wawancara untuk dapat memperluas wawasan terkait sistem yang akan dibuat. Wawancara ini penulis lakukan dengan Taufiqurrohman,Lc sebagai pembimbing praktek kerja lapangan penulis.

\section{B. Studi Literatur}

Studi literatur adalah studi yang dilakukan dengan menggunakan literatur sebagai objek kajiannya. Penulis mencari pada sumber-sumber yang otentik (internet, buku dan jurnal ilmiah). Kerangka penelitian dijelaskan dalam gambar 1

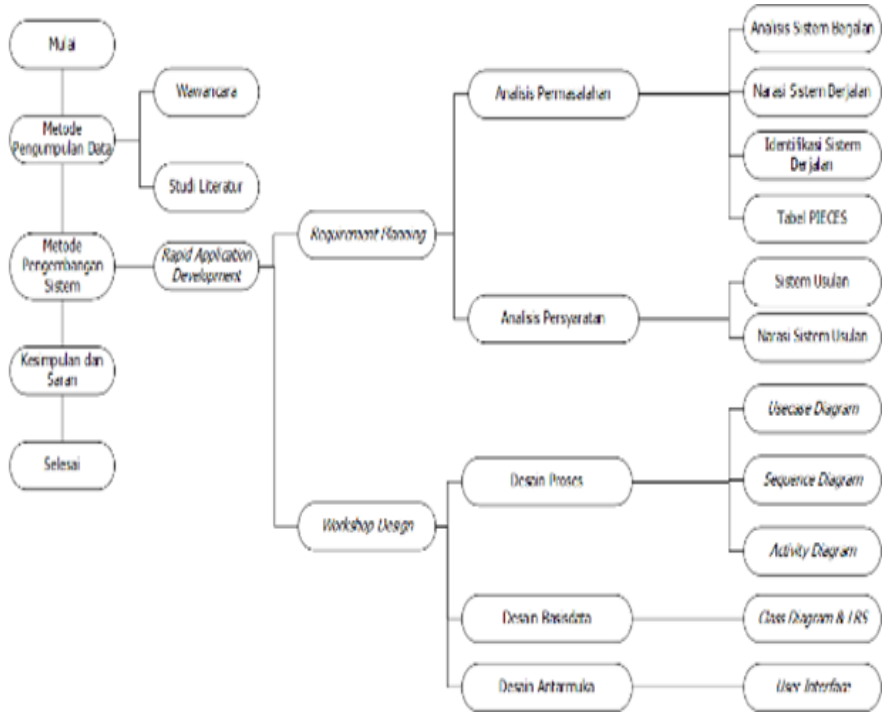

Gambar 1. Kerangka Penelitian

IV. HASIL

\section{A. Fase Requirement Planning}

\section{1) Analisis Sistem Berjalan}

Berikut ini adalah alur pendaftaran yang saat ini berjalan di Kafila International Islamic School dapat dilihat pada gambar 2.

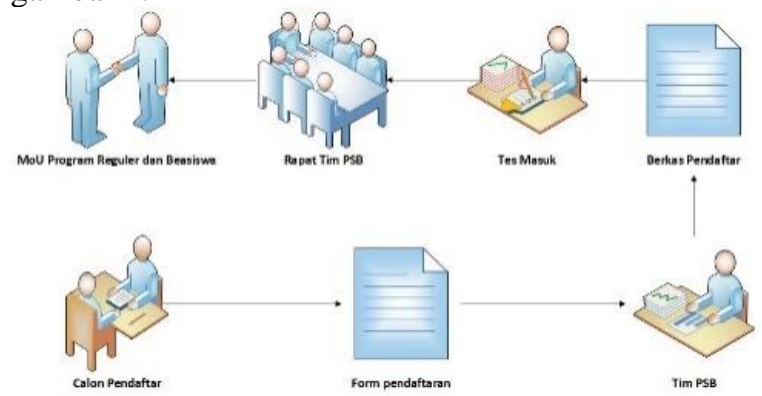

Gambar 2. Sistem Berjalan

2) Sistem Usulan

Gambar 3 merupakan alur pendaftaran yang dirancang penulis di Kafila International Islamic School. 


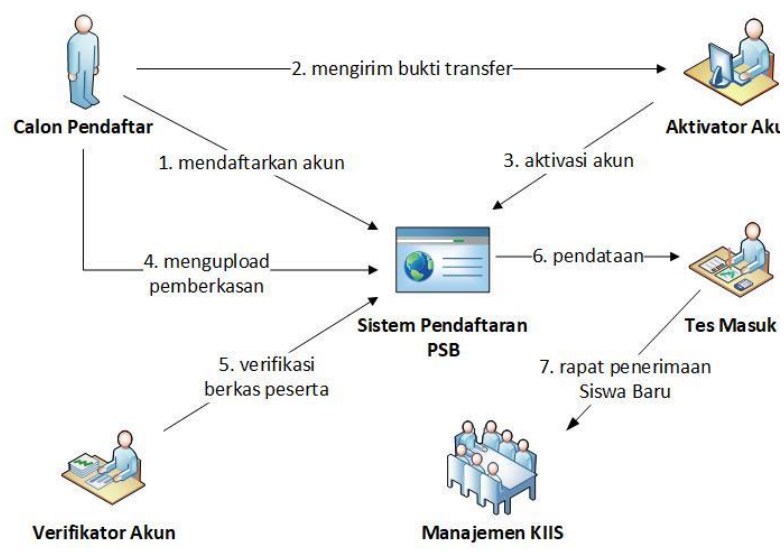

Gambar 3. Sistem Usulan

B. Workshop Design

1) Use Case Diagram

Gambar 4. adalah diagram yang menjelaskan aktivitas dalam sistem dan apa saja yang berinteraksi dengan sistem.

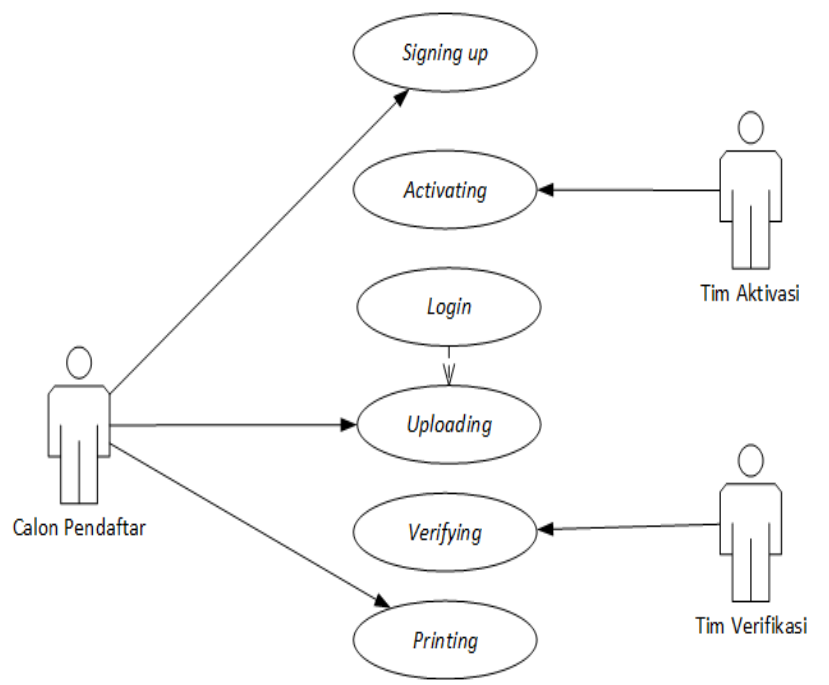

Gambar 4. Usecase Diagram

2) Sequence Diagram

Untuk menggambarkan perilaku pada skenario-skenario sistem, dibutuhkan suatu pemodelan diagram yang membantu memahami proses dari sistem ini. Pemodelan berbentuk sequence diagram dapat dilihat pada gambar 5 dan 6 , berikut adalah bentuk pemodelan sistem pendaftaran KIIS;

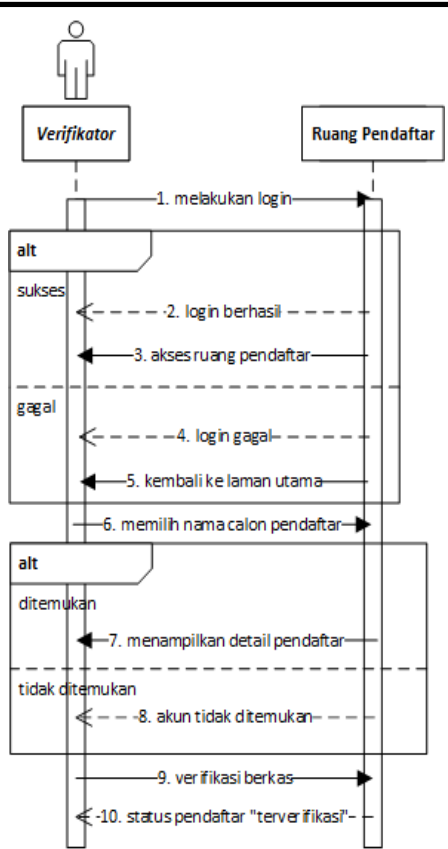

Gambar 5. Sequence Verifikasi Berkas

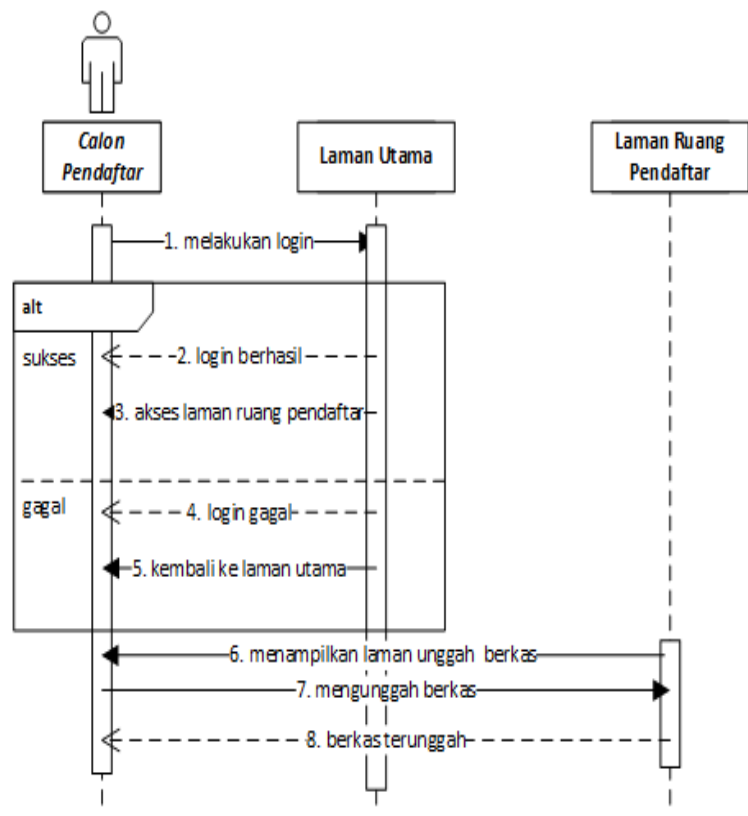

Gambar 6. Sequence Pengunggahan Berkas

3) Activity Diagram

Gambar 7 dan 8 Adalah gambaran aktifitas yang terjadi dalam sistem. Aktifitas tersebut digambarkan dalam bentuk diagram. Berikut ini adalah aktifitas yang dirancang; 


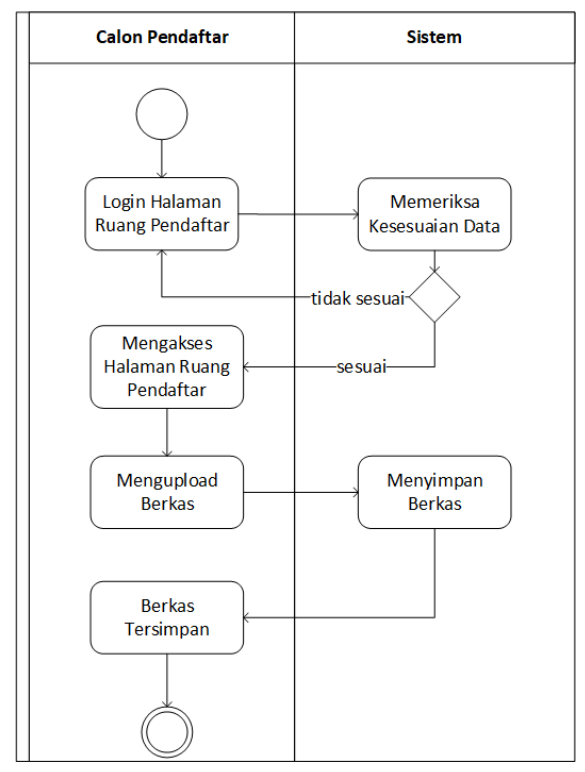

Gambar 7. Aktifitas Pengunggahan Berkas

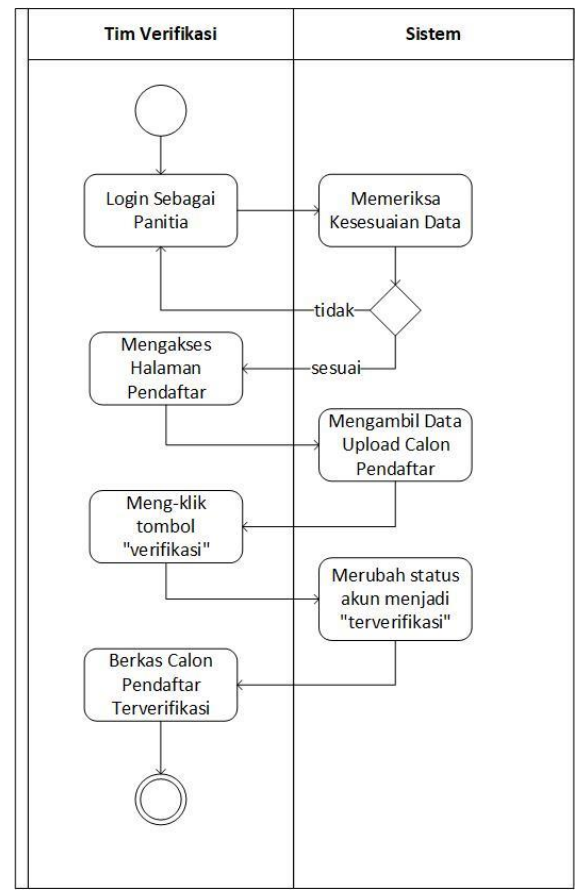

Gambar 8. Aktifitas Verifikasi Berkas

\section{4) Database Design}

Class diagram penulis gunakan untuk menggambarkan kumpulan dari class beserta hubungannya. Diagram pada gambar 9. merupakan class diagram yang penulis rancang.

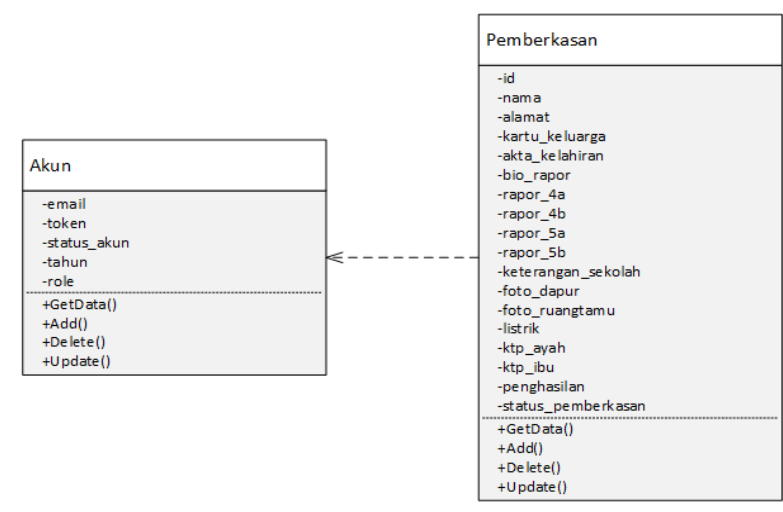

Gambar 9. Rancangan Basis Data

\section{5) User Interface}

Tampilan user interface dapat dilihat pada gambar 10 sampai dengan gambar 13, berupa menu aktivasi dan menu halaman utama, kemudian gambar 12 menunjukkan tampilan lihat calon pendaftar dan gambar 13 menampilkan menu verifikasi.

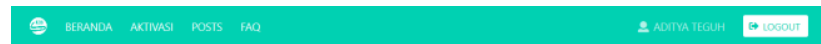

Pendaftar Aktif
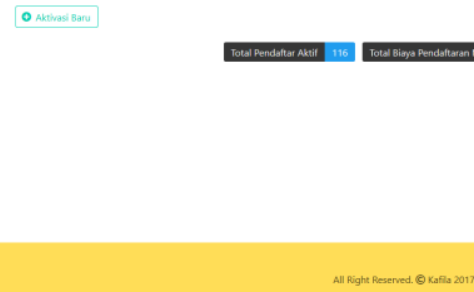

Gambar 10. Tampilan Menu Aktivasi
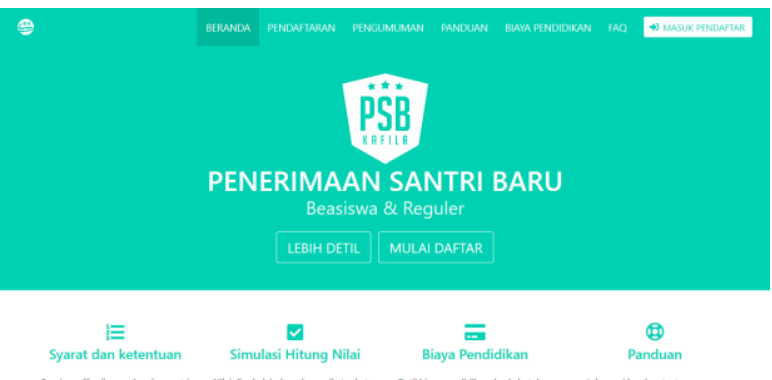

Gambar 11. Tampilan Halaman Utama 


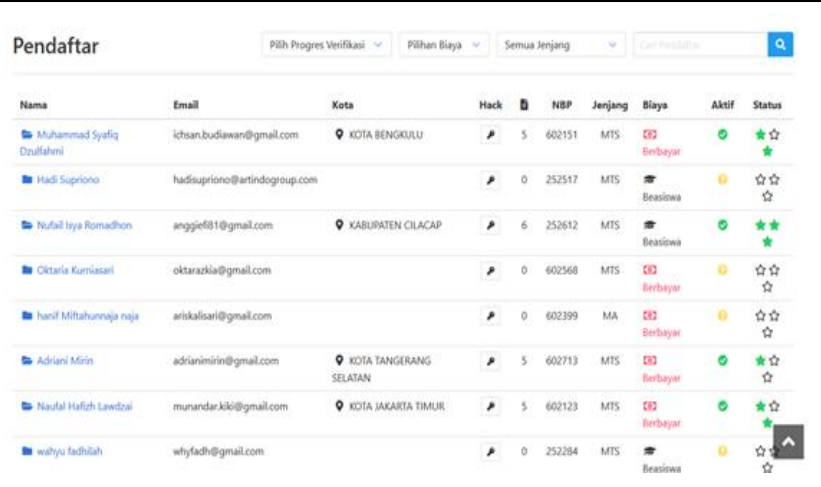

Gambar 12. Tampilan Menu Lihat Calon Pendaftar

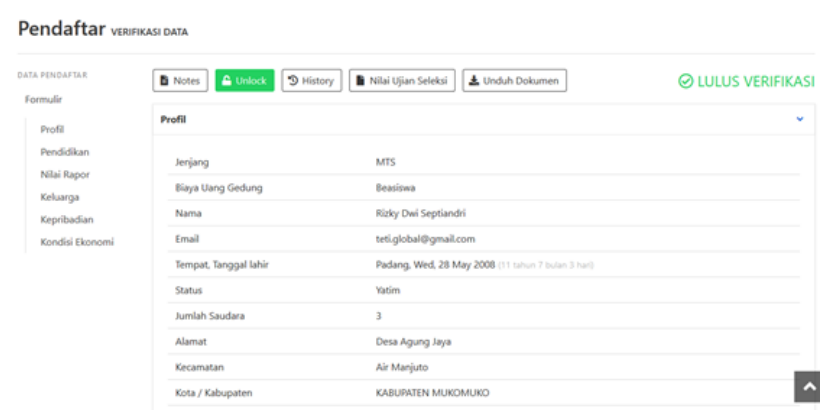

Gambar 13. Tampilan Menu Verifikasi

\section{KesimpUlan}

Berdasarkan pembahasan yang sudah diuraikan pada bab bab sebelumnya, maka dapat disimpulkan yaitu:

A. Sistem informasi spasial mitigasi bencana gunung api mengintegrasikan data mitigasi melalui pembangunan basis data mitigasi didalam sistem.

B. Sistem informasi spasial mitigasi bencana gunung api menyediakan peta digital mitigasi bencana gunung api yang dapat digunakan untuk berbagai tujuan dengan cara menggabungkan peta digital tersebut dengan peta lain sehingga menghasilkan sebuah informasi.

C. Sistem informasi spasial mitigasi bencana gunung api menyediakan pengetahuan mitigasi bencana gunung api yang dapat diakses secara online melalui media web dan mobile.

D. Sistem informasi spasial mitigasi bencana dibangun dengan menggunakan metode Rapid Application Development dengan tools Unified Modeling Language sebagai alat bantu dalam merancang sistem. Rancangan tersebut diimplementasikan kedalam bentuk program menggunakan bahasa pemograman PHP dan Java. Kemudian di uji coba dengan menggunakan metode Black box testing.

\section{REFERENSI}

[1] A. Ngafifi, "Kemajuan teknologi dan pola hidup manusia dalam perspektif sosial budaya," vol. 2, no. 1, 2014.

[2] J. S. P. Tyoso, Sistem Informasi Manajemen. Deepublish, 2016.

[3] P. A. Himawan and P. Astuti, "Perencanaan Strategis Sistem Informasi dan Teknologi Informasi Pemasaran dan Pelayanan pada Hotel (Studi Kasus: Grand Kanaya Baturraden)," vol. 10, no. 1, 2017.

http://journal.uinjkt.ac.id/index.php/aism
[4] C. Haryawan, "Sistem informasi manajemen," 2013.

[5] Y. Irawan, N. Susanti, and M. Triyanto, Elektro dan Ilmu Komputer, "Analisa Dan Perancangan Sistem Informasi Sekolah Berbasis Website Untuk Penyampaian Informasi Sekolah Dan Media Promosi Kepada Masyarakat," vol. 7, no. 1, pp. 257-262, 2016

[6] C. Sidh and Bisnis, "Peranan Brainware dalam sistem informasi manajemen," vol. 7, no. 1, pp. 19-29, 20

[7] J. Hutahaean, Konsep sistem informasi. Deepublish, 2015.

[8] A. Rusdiana, M. Irfan, and M. Irfan, "Sistem informasi manajemen," ed: Pustaka Setia, 2014.

[9] M. B. Romney and P. J. Steinbart, "Sistem informasi akuntansi," 2016.

[10] M. Safi, P. I. Santosa, and I. Ferdiana, "Pengembangan Sistem Informasi Sumberdaya Sekolah Kota Ternate Berbasis Web Dengan Metode Rapid Application Development," vol. 1, no. 2, 2016.

[11] S. Aswati and S. Siagian, "Model Rapid Application Development Dalam Rancang Bangun Sistem Informasi Pemasaran Rumah (Studi Kasus: Perum Perumnas Cabang Medan," vol. 2016, 2016.

[12] G. Lobet et al., "Root system markup language: toward a unified root architecture description language," vol. 167, no. 3, pp. 617-627, 2015.

[13] K. Lestari and K. Puspaningrum, "WEBSITE PROFIL SEBAGAI SARANA PENGENALAN SEKOLAH DENGAN PEMROGAMAN PHP DAN MySQL (STUDI KASUS: SD NEGERI BANDUNGSARI LAMONGAN)," vol. 12, no. 1, pp. 13-18, 2017.

[14] S. Edy Winarno, M. Eng, and A. Zaki, Pemrograman Web Berbasis Html 5, php, dan Javascript. Elex Media Komputindo, 2014. 